\title{
Learner Autonomy: A Central Theme in Language Learning
}

\author{
Yunus Yildiz $^{1} \&$ Hur Mustafa Yucedal ${ }^{2}$
}

\begin{abstract}
${ }^{1 \& 2}$ Department of Languages, Faculty of Education, Tishk International University, Erbil, Iraq Correspondence: Hur Mustafa Yucedal, Tishk International University, Erbil, Iraq. Email: mustafa.yucedal@tiu.edu.iq
\end{abstract}

Doi: $10.23918 /$ ijsses.v7i3p208

\begin{abstract}
Learner autonomy has been considered as a crucial affective variable in language learning. It is important for language learners to be responsible for their own learning. Recently, learners are placed at the core of language learning process. Within this context of education, learner autonomy enables learners to take active role in their own learning process. When learners take control over their learning, they develop an ability to determine their goals and objectives. Moreover, they can independently set goals, and direct their learning. Autonomy in the context of language acquisition refers to an ability to act independently and communicate in the target language in real situations. This paper endeavors to present the characteristics of autonomous learners and sets forth the relationship between autonomy and language learning.
\end{abstract}

Keywords: Learner Autonomy, Motivation, Language Learning, Responsibility

\section{Introduction}

Learners need to be prepared effectively for their future careers. It is true that if learners have the ability to manage their own learning, they will be better prepared and accomplish learning with ease. Within this context of education, the role of learner autonomy has become one of the prominent themes in teaching and learning due to its influence on helping learners reach their potential. Over the last two decades, whether there is a clear distinction between autonomous and non-autonomous learners has been debated. Learner autonomy simply is learners' taking responsibility for their own learning. In other words, the shift of control over learning occurs from teachers to learners and learners take active role in their learning process.

Affective variables might influence language learners. For instance, motivation and learner autonomy are two significant factors which might impact language learning process. It is important to point that helping learners to become independent learners is considered crucial in language education. Unless learners are motivated to learn, they will fail to develop their autonomy. The relationship between learner autonomy and effective language learning has also become a popular focus in language teaching. This study attempts to exhibit the major characteristics of autonomous learners and endeavors to put forth the role of learner autonomy on language learning.

\section{Learner Autonomy: Definitions}

Learner autonomy was first elaborated by Henri Holec (1981) who defined it as learner control. In other words, learner autonomy is helping learners to develop responsibility for their own learning. According to Benson (2001) learner autonomy is taking control over learning management, cognitive process and learning content. While control over learning management refers to behaviors learners use for planning, control over cognitive process is related to the psychology of learning. And control over learning content pertains to the freedom of learners to determine their goals and objectives. Learner autonomy on a general 
note, is a move towards more learner-centered learning and is used for situations where learners conduct learning on their own. Also, autonomous learners can apply the skills they have learned in their own learning. Moreover, such learners can independently set goals, direct and oversee their learning. Little (1991) argues that learner autonomy is "essentially a matter of the learner's psychological relation to the process and content of learning a capacity for detachment, critical reflection, decision-making, and independent action" (p. 4). Learners can act independently in their learning. In other words, freedom to a small extent is necessary to develop learner autonomy. Dickinson (1987) described autonomy as "the situation in which the learner is totally responsible for all of the decisions concerned with his learning and the implementation of those decisions" (p.11). Once again, the independence of learners has come to the fore. However, learner autonomy without teacher aid cannot be achieved. It should be kept in mind that learner autonomy is a pedagogical dialogue between learners and teacher (Benson, 2006).

Omaggio (1978) listed some major characteristics of autonomous learners:

1. They have an understanding of learning strategies and styles

2. They can look at the learning task from a different aspect

3. They are risk takers

4. They are good at guessing

Autonomous learners have the ability to implement learning strategies they have learnt from their teachers in their own learning process. As they have insights about the learning styles, they can approach tasks from different angles. In order to achieve their goals, they take risks and they can make accurate estimates. Autonomous learners are associated with motivation and aspiration. They can motivate themselves to accomplish their goals. Similarly, Holec (1981) underlies the capacities of autonomous learners and states that "autonomous learners assume responsibility for determining the purpose, content, rhythm and method of their learning, monitoring its progress and evaluating its outcomes" (p. 3 ). It is clearly emphasized that autonomous learners can organize their resources to accomplish their goals.

It should be emphasized that there is a link between motivation and autonomy and only learners with enhanced motivation take responsibility for their own learning (Ushioda, 2006; Benson, 2006; Yildiz, 2019). To put forward the link between autonomy and motivation, Ushioda emphasized the crucial role of motivation on the development of learner autonomy and argues that "without motivation, there is no autonomy" (p.40).

Learners need to achieve self-directed learning which is considered as a necessary condition for learner autonomy. Self-directed learning is "a process in which individuals take the initiative, with or without the help of others, in diagnosing their learning needs, formulating learning goals, identifying human and material resources for learning, choosing and implementing appropriate learning strategies, and evaluating learning outcomes" (Knowles, 1975, p. 18). Self-directed learning is an effective method to help learners acquire the necessary skills and abilities, and knowledge they need throughout their lives. Curiosity, aspiration and creativity are related to self-directed learning (Edmondson, Boyer, \& Artis, 2012). 
It should be kept in mind that autonomous learning does not mean learning without a teacher. On the contrary teachers "have a crucial role to play in launching learners into self-access and in lending them a regular helping hand to stay afloat" (Sheerin, 1997, p. 63). Teachers do not become redundant in autonomous learning, they show the way to learners to help them follow the path. Teachers have primary responsibility for motivating students to learn (Mart, 2011, 2013a, 2013b; Yildiz \& Celik, 2017; Yildiz, 2017). Teachers create certain conditions for learners to enable them attain learner autonomy. Regarding the significance of teacher role in fostering learner autonomy, Johnson, Pardesi and Paine (1990) argue that learner autonomy is contingent upon teacher autonomy because 'teachers' autonomy permeates into learners' autonomy' (Johnson, Pardesi, \& Paine, 1990, p.51).

Traditional classroom does not promote learner autonomy. Therefore, teachers need to create new ways of teaching in which learners have some degree of freedom about their learning. In a teacher-centered approach, learners cannot find adequate number of options to develop their self-directed learning. Learners should be provided opportunities in which they manage their own learning.

\section{Learner Autonomy in the Context of Language Acquisition}

Littlewood (1997, p.81) proposed a three-stage model about levels of learner autonomy in language learning.
a) Language acquisition
b) Learning approach
c) Personal Development

Autonomy in the context of language acquisition refers to an ability to act independently and communicate in the target language in real situations. For increasing learners' proficiency in language, the effective use of target language is essential (Mart, 2012). Autonomy in the context of learning approach involves ability to control over one's own learning and apply relevant strategies. And autonomy in the context of personal development is related to attaining autonomy with a higher level. Likewise, Macaro (2000) proposed a three-stage autonomy model in language learning (pp. 170-172):
a) Autonomy of language competence
b) Autonomy of language learning competence
c) Autonomy of choice and action

Benson (2006, p.24) has also a three-stage model about levels of learner autonomy in language learning.
a) Learning management
b) Cognitive processing
c) The content of learning

All of these models proposed by different researchers aim to develop learner autonomy. A great many factors including affective and cognitive variables influence language learning. The concept of learning strategy, for instance, is in the focus of interest in the development of learner autonomy (Huang, 2006). Motivation is a crucial factor for attaining autonomy and encourages learners for active involvement in the language learning process. Additionally, individual differences are also related to the achievement of 
learner autonomy. Finally, teacher autonomy is one of the most important factors which influence learner autonomy. It goes without saying that teacher autonomy and learner autonomy are linked to each other. Teacher autonomy refers to teachers' having freedom in curriculum implementation (Benson, 2006). Teacher autonomy also includes professional development. Teacher development holds an important place in education as teachers need to "create educationally sound, contextually appropriate, and socially equitable learning opportunities for the students they teach" (Johnson, 2006, p.235).

The development of autonomy leads to better language learning. The link between learner autonomy and effective language learning has been largely explored in researches. Corno and Mandinach (1983) in their study found that learner autonomy implied better acquisition of language proficiency. Zhang and $\mathrm{Li}$ (2004) pointed out that autonomous learners achieved high scores in a language test. It is possible to conclude that learner autonomy is a significant factor for the development of language proficiency.

\section{Conclusion}

Learner autonomy has gained momentum in language education recently. It is true that if learners have the ability to manage their own learning, they can reach their potential with ease. For that reason, in order for language proficiency development, learners should develop responsibility for their own learning. Learner autonomy is a move towards more learner-centered learning in which learners conduct learning on their own. Also, autonomous learners can apply the skills they have learned in their own learning and they can independently set goals, direct their learning. Autonomy in the context of language acquisition refers to an ability to act independently and communicate in the target language in real situations. Autonomous learners have the potential to acquire the necessary skills and abilities, and knowledge they need for language development.

\section{References}

Benson, P. (2006). Autonomy in language teaching and learning. Language Teaching, 40, 21-40. Corno, L., \& Mandinach, E. B. (1983). The role of cognitive engagement in classroom learning and motivation. Educational Psychologist, 18(2), 88-108.

Dickinson, L. (1987). Self-instruction in language learning. Cambridge: Cambridge University Press.

Edmondson, D. R., Boyer, S. L., \& Artis, A. B. (2012). Self-directed learning: A meta-analytic review of adult learning constructs. International Journal of Education Research, 7(1), 40-48.

Holec, H. 1981. Autonomy in foreign language learning. Oxford: OUP.

Huang, J. (2006b). Learner resistance in metacognition training? An exploration of mismatches between learner and teacher agendas. Language Teaching Research, 10.1 95- 117.

Knowles, M. (1975). Self-directed learning: A guide for learners and teachers. New York: Cambridge Books.

Johnson, J., Pardesi, H., \& Paine, C. (1990). Autonomy in our primary school. In Gathercole, I. (1990). Autonomy in language learning. CILT: Bourne Press.

Johnson, K. E. (2006). The sociocultural turn and its challenges for second language teacher education. TESOL Quarterly, 40(1), 235-257.

Little, D. 1991. Learner Autonomy. 1: Definitions, Issues and Problems. Dublin: Authentik.

Littlewood, W. (1997). Self-access: Why do we want it and what can it do? In Benson \& Voller (eds.), 79-92.

Mart, Ç.T. (2012). Developing speaking skills through reading. International Journal of English Linguistics, 2 (6), 91-96. 
Mart, Ç. T. (2011). How to sustain students' motivation in a learning environment. Retrieved from ERIC database: ED519165.

Mart, Ç.T. (2013a). A passionate teacher: Teacher commitment and dedication to student learning. International Journal of Academic Research in Progressive Education and Development, 2(1), 437-442.

Mart, Ç.T. (2013b). Commitment to school and students. International Journal of Academic Research in Business and Social Sciences, 3(1), 336-340.

Omaggio, A. (1978). Successful language learners: What do we know about them? ERIC / CLL News Bulletin, May, 2-3.

Sheerin, S. 1997. An Exploration of the Relationship between Self-access and Independent Learning. In Benson, P. and Voller, P. (eds.). 1997. Autonomy and independence in language learning. London: Longman.

Ushioda, E. (1996). Learner autonomy 5: The role of motivation. Dublin: Authentik.

Ushioda, E. (2006). Motivation, autonomy and sociocultural theory. In Benson (ed.), 5-24.

Yildiz, Y., \& Celik, B. (2017). Commitment to the teaching profession. International Journal of Social Sciences \& Educational Studies, 4(2), 93-97.

Yildiz, Y. (2017). Components of Commitment to the Teaching Profession. International Journal of Social Sciences \& Educational Studies, 4(2), 115-122.

Yildiz, Y. (2019). A Tiny Comment to Utilizing Religious Sources to Create Environment Friendly Citizens. Asian Social Science, 15(6), 1-5

Zhang, L.X., \& Li X.X. (2004). A comparative study on learner autonomy between Chinese students and west European students. Foreign Language World, 4, 15-23. 